\title{
Osmaniye İlinin Coğrafi İşaretli Ürün Potansiyelinin Değerlendirilmesi
}

\author{
Evaluation of the Potential of Osmaniye in Terms of the Products with Geographical Indication
}

\author{
Meral Üzülmez*
}

${ }^{1}$ Department of Gastronomy and Culinary Arts, Osmaniye Korkut Ata University, Osmaniye, Turkey

\begin{abstract}
\begin{tabular}{lllll} 
Received: 18.02 .2020 & Accepted: 22.06 .2020 & This article was checked by intihal.net & ISSN: 2149-8598 \\
\hline
\end{tabular}
$\ddot{0} \mathbf{z}$

Coğrafi işaretler, yöresel ürün ve lezzetlerin korunmasını ve taklitlerine karşı yasal olarak mücadele edilmesini sağlayan işaretlerdir. Coğrafi işaretlerin, yerel üretimi ve bölgesel gelişimi desteklemesi, geleneksel bilgi ve kültürel değerleri koruması ve turizme katkı sağlaması gibi birçok avantajı bulunmaktadır. Bir bölgede/yörede coğrafi işaret tescili alabilecek ürünler, gıda ürünleri, tarımsal ürünler olabileceği gibi; el sanatları, sanayi ürünleri, maden ve doğal ürünler de olabilmektedir. Bu kapsamda çalışmada, Osmaniye ilinin coğrafi işaretli ürün potansiyelinin incelenmesi amaçlanmıştır. Çalışmada, nitel araştırma yöntemi kullanılmıştır. Bu kapsamda, veriler, nitel araştırma yöntemlerinden olan arşiv-doküman tarama tekniğiyle elde edilmiştir. Elde edilen veriler, betimsel analize tabi tutulmuştur. Çalışma sonucunda, Osmaniye ilinde coğrafi işaret potansiyeli taşıyan ürünlerin genellikle, tarımsal ve el sanatları ürünleri olduğu ortaya çıkarılmıştır. Çalışmada, Osmaniye ilinin coğrafi işaret potansiyeli taşıyan ürünlerinin tescil alabilmesi ve bu ürünlerin bölgeye katkı sağlaması amacıyla ilgili kişi, kurum veya kuruluşlara çeşitli öneriler sunulmuştur.
\end{abstract}

Anahtar Kelimeler: Osmaniye, Coğrafi işaret, Coğrafi işaret potansiyeli.

\begin{abstract}
Geographical indications are the legal indications for protecting local products and flavors and legally fighting against their counterfeits. Geographical indications have many advantages such as supporting local production and regional development, protecting traditional knowledge and cultural values and contributing to tourism. The products that may have geographical indication registration in a region/locality can be both food products, agricultural products and handicrafts, industrial products, minerals and natural products. In this context, it is aimed to investigate the potential of Osmaniye in terms of the products with geographical indication. It was used qualitative research method in the study. In this context, it was obtained data by using archive-document scanning technique that is one of the qualitative research methods. The obtained data were subjected to descriptive analysis. As a result of the study, it was determined that products with the potential of geographical indication (sign) are generally agricultural and handicraft products in Osmaniye province. In the study, various suggestions were presented to the related persons, institutions or organizations to make the registration possible for the products with potential for geographical indication and to provide that such products contribute to the region.
\end{abstract}

Keywords: Osmaniye, Geographical Indication, Potential for Geographical Indication.

JEL Codes: M00, R11, L83

Üzülmez, M. (2020). “Osmaniye İlinin Coğrafi İşaretli Ürün Potansiyelinin Değerlendirilmesi”, Journal of Academic Value Studies, 6(2) 188-196 (http://dx.doi.org/10.29228/javs.41832).

\footnotetext{
*E-mail address: meraluzulmez@osmaniye.edu.tr
} 


\section{Giriş}

Coğrafi işaret, ürünleri taklitlerinden ayırt etmeye yarayan ve kullanıldıkları ürünleri farklılaştıran işaretler olarak ifade edilmektedir (Dağtekin, 2018: 853). Coğrafi işaret tescili, ilgili kurum ve kuruluşlar tarafından genel olarak, yöresel ürünlerinin korunması, tanıtımının yapılması, bölgesel/kırsal ekonominin canlandırılması (Kan ve Gülçubuk 2008: 59-60) ve coğrafi işaretlerin ait oldukları yörenin/bölgenin ismiyle anılmasından dolayı tercih edilmektedir (Toprak ve Oğuz, 2017: 964). Bu bağlamda, coğrafi işaret tescili, ürünlere ayırt edicilik kazandırma, coğrafi kaynak belirtme, pazarlama aracı olma ve üretim tekniğini/yöntemini ve kaliteyi garanti etme gibi fonksiyonlar kazandırmaktadır (Doğan 2015: 18). Coğrafi işaretlerin bu işlevleri sayesinde, yerel ürünlerin değeri artmakta (Bramley ve Kirsten, 2007: 70) ve yerel ürünlerin kimliği korunmaktadır (Suh ve MacPherson, 2007: 519). Türkiye'de geleneksel ve yerel birçok ürünün varlığı ve bu ürünlerin kendine has özellikleri olması, bu değerlerin korunma olgusunu gündeme taşımaktadır (Öz ve Dönmez, 2018: 263). Coğrafi işaretler ile koruma altına alınmış yerel ürünler, Türkiye ekonomisi için önemli bir potansiyel oluşturmaktadır. Ürünlerin coğrafi işaret tesciliyle korunması ve üretimi sayesinde yaratılacak olan istihdam ve katma değer, bölge nüfusunun ekonomik kalkınmasında önemli bir rol oynamakta ve yaratılan katma değer ise bölgeler arasındaki gelir dağılımı üzerine olumlu katkı sağlamaktadır (Kantaroğlu ve Demirbaş, 2018: 515). Agostino ve Trivieri (2014) coğrafi işaretli ürünlerin, yerel halka istihdam olanağı sağlamasının farklı şehirlere göçü önleyerek kırsal ve kentsel alanlar arasındaki dengenin korunmasına da katkıda bulunduğunu belirtmektedir. Türk Patent Enstitüsü'nün (TPE) verilerine göre, 2020 Şubat ayı itibariyle Türkiye'de toplamda 455 adet ürünün coğrafi işaret tescili aldığı ortaya çıkmaktadır (TPE, 2020). Coğrafi işaretlerin kapsamı, Osmaniye ili açısından değerlendirildiğinde ise gerek tarihi gerekse de coğrafi yapısındaki çeşitlilik, ilin kendine has değerler oluşturmasında önemli rol oynamaktadır. Ancak, Osmaniye ili coğrafi işaret potansiyeli açısından zengin olarak değerlendirilmesine rağmen, bugüne kadar Türk Patent Enstitüsüne (TPE) başvurularak tescil alınmış olan sadece bir ürünü bulunmaktadır. Bu kapsamda, Osmaniye'de ilk coğrafi işaret başvurusu, yer fıstığı üzerine Osmaniye Ticaret Borsası tarafından 2002 yılı içerisinde yapılmıș ve TPE tarafından 18.06.2003 tarihinde yer fistığı, menșe ișareti olarak tescillenmiștir (TPE, 2019). Tek bir ürün tescil almasına rağmen, tarımsal ve coğrafi özellikleriyle Türkiye'nin önemli bir tarım merkezi olan, mutfağında kendine özgü lezzetleri barındıran ve yemek kültürü olarak da çeşitlilik gösteren Osmaniye ilinin (Üzülmez ve Akdağ, 2019: 458) coğrafi işarete konu olabilecek birçok ürünü bulunmaktadır. Bu bağlamda çalışmada, Osmaniye ilinin coğrafi işaret kapsamında değerlendirilen ve/veya değerlendirilebilme potansiyeli taşıyan ürünlerini tespit etmek ve bu ürünlere dikkat çekmek amaçlanmaktadır.

\section{Coğrafi İşaret Kavramı}

Coğrafi işaret kavramı, belirgin bir niteliği, ünü ya da diğer nitelikleri bakımından kökenin bulunduğu bir yöre, alan, bölge ya da ülke ile özdeşleşmiş bir ürünü gösteren işaret olarak ifade edilmektedir (Schneider ve Ceritoğlu, 2010: 29). Bir başka ifadeyle coğrafi işaretler, kaliteli ve belirli bir karakteristik özelliğe sahip olan ve ürünün karakteristik özelliği ile kökeninin bulunduğu coğrafya arasında bağlantılı ürünler olarak da tanımlanmaktadır (Chandola, 2006: 168). Şahin (2013: 482) ise coğrafi işareti, kendine has veya birden fazla özelliği bulunan ve sınırları belirli bir alana özgü ürünü ait olduğu bölgenin markası veya işareti haline getirme süreci olarak belirtmektedir. Dolayısıyla, coğrafi işaret sistemiyle, koruma altına alınan ürün ile ürünün üretildiği yöre arasında bir ilişki kurulmaktadır (Dimara, Petrou ve Skuras, 2004: 486). Coğrafi işaretler; menşe (köken) ve mahreç (çıkış) işareti olarak iki farklı şekilde sınıflandırılmaktadır. Coğrafi işaret korumasına konu olan ürünün üretimi, işlenmesi ve diğer işlemlerinin tümü sınırları belirli olan coğrafi bölgede gerçekleştirilmek zorunda ise bu ürün için menşe adı alınmaktadır. Örneğin, Anzer Balı, Aydın İnciri ve Taşköprü Sarımsağı menşe adı olarak işaretlenmiştir (Artık, Şanlıer ve Sezgin, 2019: 348-349). Mahreç işaretinde ise ürünün üretimi, işlenmesi ve diğer işlemlerden en az birisinin belirli yöre, alan ya da bölge sinırlarında yapılması gerekmektedir (Dede ve Didin, 2017: 98-99). Dolayısıyla, mahreç işaretinde önemli olan nokta, ürünün üretiminde ait oldukları coğrafi alana özgü hammadde ve üretim tekniklerinin kullanılmasıyla birlikte ürünün kalitesinin aynı olmasına dikkat edilmesidir (Artık, Şanlıer ve Sezgin, 2019: 349). Bir ürünün coğrafi işaret olarak değerlendirilmesi için ilk olarak söz konusu işaretin bir ürünü belirtmesi gerekmektedir. Sonrasında ise coğrafi işarete konu olan ürün, sınırları belirlenmiş bir coğrafyayı kapsamalı ve belirli bir karakteristik özellik taşımalıdır. Ayrıca, ürünün karakteristik özelliği ve coğrafi kökeni arasında bir ilişkinin söz konusu olması da ürünün coğrafi işaret olarak değerlendirilmesi için gerekli olan unsurlardır (Kan ve Gülçubuk, 2008: 59).

Coğrafi işaret kavramının, yöresel ürünlerin korunabilmesi ve söz konusu ürünlerin kaynăg olan yörelerde/bölgelerde yaşayan bireylerin coğrafi işaretin sağladığı faydalardan yararlanması amacıyla ortaya 
çıktığı belirtilmektedir (Suratno, 2004: 89). Bu bağlamda, coğrafi işaret korumasının çok yönlü ekonomik, sosyal ve kültürel etkileri mevcuttur. Coğrafi işaret, üreticinin standart bir kalitede üretim yapmasını özendirerek üreticilerin devamlı olarak gelir elde etmesine katkı sağlamakta (Gökovalı, 2007: 149) ve söz konusu standart üretimi yapan tüm üreticileri koruma altına almaktadır (Babcock ve Clemens, 2004: 13). Ayrıca, bir ürünün coğrafi işaret koruması alması, sadece maddi kazançların elde edilmesine katkı sağlamamakta, aynı zamanda geleneksel olan bilgi ve üretim yöntemlerinin korunması (Rangnekar, 2004: 6) ve kültürel mirasın sürdürülmesine de katkı sağlamaktadır (Zografos, 2008: 11). Coğrafi işaretler, ürünü üreten üreticiyi koruduğu gibi tüketiciyi de ürünün taklitlerine karşı uyararak onlara da yol göstermektedir (Lucatelli, 2004: 12). Ayrıca, coğrafi işaretler, ortak bir gelenek ve karar verme sürecine bağlı olduğu için insan işgücü ve emeği, kültür, doğal kaynaklar, toprak ve çevre arasında sıkı bir bağ oluşturmaktadır (Bucak, 2018: 376). Treager ve diğ. (2007) coğrafi işaretlerin yerel kalkınmada sağladığı faydaları; koruma aracı, ekonomik denge sağlama aracı, pazarlama aracı, kırsal kalkınma aracı ve bilgi aracı olmak üzere beş temel başlıkta sınıflandırmaktadırlar. Addor, Thumn ve Grazioli (2003) de benzer şekilde, coğrafi işaretlerin etkili bir reklam aracı olarak değerlendirilebileceğini belirtmektedir. Dolayısıyla, coğrafi işaretli ürünlerin üretildiği bölgede birçok işlevi yerine getirdiği ortaya çlkmaktadır.

\section{Alanyazın Taraması}

Coğrafi işaret kavramının incelendiği çalışmalar, farklı başlıklar halinde alanyazında yer almaktadır. Bunlar; genel olarak coğrafi işaretli ürünlerle gastronomi arasındaki ilişkinin incelenmesine yönelik çalışmalar (Üzümcü, Alyakut ve Akpulat, 2017; Yeşildağ, Özata ve Akkaya, 2017; Hazarhun ve Tepeci, 2018), coğrafi işaretli ürünlerin turizmle olan ilişkisine yönelik çalışmalar (Mercan ve Üzülmez, 2014; Hatipoğlu, 2016; Polat, 2017), coğrafi işaretli gıda ürünlerinin incelenmesine yönelik çalışmalar (Dikici, Koluman ve Aktaş, 2013; Kantaroğlu ve Demirbaș, 2018), coğrafi ișaret tescili almış olan ürünlerin ele alındığı çalıșmalar (Bowen ve Zapata, 2009; Arfini, Albisu ve Giocomini, 2011; Jay ve Taylor 2013; Şahin, 2014; Demir, 2016; Toprak ve Oğuz, 2017; Kaya ve Şahin, 2018), coğrafi işaret potansiyeli olan ürünlerin incelendiği çalışmalar (Çalışkan ve Koç, 2012; Ramos, Fernandes ve De Souza 2012; Çekal ve Aslan, 2017; Dayısoylu, Yörükoğlu ve Ançel, 2017; Arslaner ve Salık, 2018; Bulut ve Fural, 2018; Dağtekin, 2018), coğrafi işaretlerin ekonomik açıdan incelenmesine yönelik çalışmalar (Bramley ve Kirsten, 2007; Suh ve MacPherson, 2007; Coombe, Ives ve Huizenga, 2014, Gangjee; 2015), coğrafi işaretli ürünlerin bölgesel/kırsal kalkınmadaki rolüne yönelik çalışmalar (Gürel vd., 2016; Çukur ve Çukur, 2017), coğrafi işaretli ürünlerle marka/markalaşma kavramının ele alındığı çalışmalar (Şahin, 2017; Acar, 2018) şeklinde gerçekleştirildiği ortaya çıkmaktadır.

Suh ve MacPherson (2007) çalışmalarında, bölgesel ekonomiyi canlandırması için Güney Kore'de coğrafi işaret potansiyeli taşıyan Boseong isimli yeșil çayı incelemişlerdir. Bu kapsamda, Boseong adlı yeşil çayın coğrafi işarete sahip olmasıyla birlikte pazarda bu ürünün bilinirliğinin ve üretim miktarının arttığı tespit edilmiștir.

Ramos, Fernandes ve De Souza (2012) çalışmalarında, tarımsal ürünleriyle coğrafi işaret açısından önemli bir potansiyele sahip olan Brezilya'yı inceleme konusu yapmışlardır. Bu bağlamda, Brezilya'daki coğrafi işaret potansiyeli taşıyan ürünlerin bir envanterini oluşturarak coğrafi işaretli ürün sayısının artırılması için gerek devlet gerekse de toplumun daha bilinçli davranması gerektiğini belirtmişlerdir.

Jay ve Taylor (2013) çalışmada, Avrupa ve Fransa'daki coğrafi işaretlerin hukuksal sürecine ve kapsamına yer vermişlerdir. Ayrıca çalışmada, Fransa'nın Champagne bölgesinde üretilen ve coğrafi işaret tesciliyle koruma altına alınan Champagne köpüklü şarabının Fransa'nın tanıtımına katkı sağlama ve söz konusu bölgeye turist çekme açısından önemli bir araç olduğu vurgulanmıştır.

Mercan ve Üzülmez (2014) yaptıkları araștırmada, Çanakkale ilinde coğrafi işaret sistemiyle koruma altına alınan ürünlerin, bölgesel turizm gelişimindeki önemini inceleyerek, bu ürünlerin bir turistik ürün olarak ne şekilde değerlendirilebileceğini araştırmışlardır. Bu bağlamda, Çanakkale'de ilgili kurum ve kuruluş temsilcileriyle görüştükleri çalışma sonucunda, Çanakkale'nin coğrafi işarete sahip olan ürünlerinin özenli bir biçimde tanıtım ve pazarlama çalışmalarının yapılması sayesinde bölgesel turizm gelişimi açısından bir araç görevi üstlenebileceğini tespit etmişlerdir.

Üzümcü, Alyakut ve Akpulat (2017) çalışmalarında, Kocaeli'nin coğrafi işaret potansiyeli taşıyan gastronomik ürünlerinin ortaya çıkarılmasını amaçlamışlardır. Bu bağlamda, Suadiye Kokulu Üzümü, Fıstıkoli, Malahto, Sızbal, Papaz Yahnisi, Kırma Böreği, Çarşaf Böreği, Silor, Umaç Çorbası, Dartılı Lokum, Dartılı Düdük Makarna, Höşmerim, Maşukiye Çerkez Peyniri, Çerkez Tavuğu, Kuru Helva, Nazlı, Cızlama, Üre ve Abaza Pastası gibi ürünlerin coğrafi işaret potansiyeli taşıdığı tespit edilmiştir. 
Hazarhun ve Tepeci (2018) çalışmalarında, Manisa'da coğrafi işarete sahip ürün ve yiyeceklerin/yemeklerin gastronomi turizmine olan katkısını ortaya çıkarmaya çalışmışlardır. Bu bağlamda, çalışma amacına bağlı olarak Manisa ili, Akhisar Domat Zeytin, Akhisar Uslu Zeytin, Akhisar Köfte, Salihli Kiraz, Salihli Odun Köfte ve Kırkağaç kavunu olmak üzere toplamda altı coğrafi işaretli ürüne dikkat çekilmiştir. Çalışma sonunda, Manisa'nın gastronomi turizminin gelişimine katkı sağlaması amacıyla, coğrafi işarete sahip ürünlerin ve yemeklerin kamu, özel sektör ve yerel yönetimler tarafından tanıtılmasına özen gösterilmesi konusunda öneriler sunulmuştur.

\section{Yöntem}

Çalışmanın amacı, Osmaniye ilinin coğrafi işaret potansiyelini ortaya çıkarmaktır. Söz konusu amacı gerçekleştirebilmek için Osmaniye ilinde çeşitli kurum ve kuruluşlar tarafından, coğrafi işaret tescil başvuru aşamasında incelemesi devam eden veya tescil alma potansiyeline sahip olduğu düşünülen ürünler incelenmiştir. Bu kapsamda, çalışmada nitel araştırma yönteminden yararlanılmıştır. Araştırma verilerinin oluşturulmasında, nitel araştırma yöntemlerinden olan arşiv-doküman tarama tekniği kullanılmıştır. Yıldırım ve Şimşek (2013: 217), arşiv-doküman tarama tekniğini, "incelenmesi amaçlanan olgu veya olgular hakkında bilgi içeren yazılı materyaller" olarak ifade etmektedir. Bu bağlamda, söz konusu araştırma tekniği kullanılarak Osmaniye ilinin potansiyel coğrafi işaretlerine yönelik elde edilmiş olan veriler, betimsel analize tabi tutularak yorumlanmıştır.

\section{Bulgular}

Çalışmada, elde edilen veriler doğrultusunda Osmaniye ilinin coğrafi işarete konu olabilecek birçok ürünü olduğu ortaya çıkmıştır. Söz konusu bu ürünlerin gıda, tarımsal ürünler ve el sanatları ürünleri gibi farklı alanlarda olduğu görülmektedir. Aşağıda coğrafi işaret potansiyeli olan bu ürünlere yer verilmektedir.

Kadirli Turpu: Osmaniye ilinin Kadirli ilçesinde, TPE nezdinde başvuru aşamasında olan bir adet ürünü bulunmaktadır. Bu ürün, Kadirli Turpu'dur ve 01.06.2018 tarihinde resmi başvuru sahibi olan Osmaniye Ticaret Borsası tarafından menşe adı kapsamında TPE'ye tescil başvurusunda bulunulmuştur (TPE, 2019). Turp (Raphanussativus L.), Brassicaceae (Cruciferae) familyasına ait olup insanların taze sebze ihtiyacını karşılamada önemli yeri olan ve besin içeriği bakımından zengin bir sebzedir (Akan vd. 2013: 289). Üretim yeri, Kadirli merkez ve Sumbas ilçesi olarak belirtilen Kadirli turpunun, kırmızı Kadirli turpu olarak bilindiği ve genellikle bu türünün üretildiği belirtilmektedir. Ayrıca Türkiye'de üretimin yaklaşık olarak \%70'inin Kadirli ilçesinden sağlandığı vurgulanmaktadır (Kadirli Belediyesi, 2019). Bu bağlamda, menșe adıyla alınacak olan coğrafi işaret tescilinin Kadirli turpuna olan ilgiyi artıracağı ve kökeninin olduğu bölgenin tanıtımına katkı sağlayacağı söylenebilir.

Osmaniye Karatepe Kilimleri: Osmaniye ilinin, TPE gözetiminde başvuru aşamasında olan bir diğer ürünü, Osmaniye Karatepe Kilimi'dir. Bu ürün, 26.04.2019 tarihinde resmi başvuru sahibi olan Osmaniye Kültür Turizm ve Kalkındırma Derneği tarafından menşe adı kapsamında TPE’ye tescil başvurusu yapılmıştır (TPE, 2019). Karatepe, Osmaniye’ye $30 \mathrm{~km}$. mesafede olan, doğusunda Düziçi ve Bahçe, batısında Kadirli ilçeleri bulunan bir köydür. Karatepe kilim üretimi, 1972 yılında bașta 16 köyün katılımıyla kurulan Karatepe Kilim Kooperatifi sayesinde başlamış; ancak ilerleyen yıllarda kilim üretimi sadece Karatepe köyünde devam etmiştir. Karatepe kilimlerini diğer kilimlerden ayıran en önemli özellik, \%100 yün iplikler kullanılması ve ipliklerde kullanılan boyaların özelliğidir. İplikler; ağaçların kökleri, yaprakları ve çiçeklerden elde edilen doğal kök boyalarıyla boyandığı için günește de solmamaktadır. Ayrıca, kilimlerin dokuması titiz bir süreci gerektirdiği için 1 metrekare kilimin dokuması yaklaşık 6-7 günü bulmaktadır (Doğu Akdeniz Kalkınma Ajansı, 2018: 63-64). Dolayısıyla, başvuru aşaması devam eden Karatepe Kilimleri'nin kendine özgü özelliklerinin korunması amacıyla coğrafi işaret tescili alması hem bölgeye olan ekonomik katkının hem de bölgenin bilinirliliğinin artmasına katkı sağlayacaktır.

Defne Yaprağı: Defne yaprağı ile ilgili Osmaniye ilinde herhangi bir kurum ya da kuruluş tarafından TPE'ye resmi olarak bir başvuru olmamasına rağmen, defne yaprağının coğrafi işaretli ürün potansiyeli taşıdığı söylenebilir. Defne, bilimsel olarak "Laurus Nobilis" olarak bilinmekle birlikte, Osmaniye'de "har ve teynel" gibi isimlerle de kullanılmaktadır (Karık vd. 2015: 2). Osmaniye'de üretimi yoğun bir şekilde yapılan defne yaprağının üretim sınırları, Kadirli ve Sumbas ilçelerine bağlı Değirmendere, Koçlu, Tahta, Yeşilyayla, Yoğunoluk ve Kösepınarı köyleri olarak belirtilmektedir (Doğu Akdeniz Kalkınma Ajansı, 2018: 66). Defne yaprağı, genellikle ilaç, gıda, kimya, boya ve kozmetik gibi birçok sektörde ham madde olarak kullanılmaktadır (www.milliyet.com.tr). Bu bağlamda, defne yaprağının kullanım alanını düşünüldüğünde, defne yaprağından elde edilecek olan gerek defne yağının gerekse de defne yağından elde edilebilecek şampuan ve sabun gibi 
ürünlerin Osmaniye ili için coğrafi işaretli ürün potansiyeli taşıyabileceği belirtilebilir. Bu nedenle, Osmaniye'de ilgili kurum veya kuruluşların defne yaprağı ya da türevlerinden yapılan/yapılacak olan ürünlerine, ürün özelliğini de dikkate alarak menșe ya da mahreç olarak tescil başvurusu yapabileceği söylenebilir.

Osmaniye Zeytinyağı: Osmaniye'de özellikle 2006 yllından itibaren zeytin üretiminin arttığı ve zeytinlerin \%72 'sinin yağlık, \%28 'inin ise sofralık olarak değerlendirildiği belirtilmektedir (Osmaniye Ticaret ve Sanayi Odası, 2018). Osmaniye ilinin genel olarak, yağlık zeytin çeșidine odaklandığı ve Türkiye'de 2018 yllı verilerine göre; yağlık zeytin üretiminde Osmaniye'nin 7. sırada yer aldığı belirtilmektedir (Doğu Akdeniz Kalkınma Ajansı, 2018). İlde üretilen yağlık zeytin çeşitlerinin Edremit, Kilis ve Gemlik çeşitleri olduğu görülmektedir. Osmaniye'de zeytin üretiminin yoğun olarak yapıldığı yerler; Merkez İlçe Akyar, Fakıuşağı, Dereobası, Çona, Çardak, Kırıklı, Kırmacılı köyleri ile Düziçi, Kadirli, Sumbas ve Toprakkale ilçeleri olarak ön plana çıkmaktadır. İl genelinde toplam 12 adet zeytinyağı işleme tesisi bulunmakta ve bölgede yetiştirilen zeytinler sadece mekanik yöntemlerle işlenerek herhangi kimyasal işlemlere tabi tutulmadan hazırlanmaktadır. Bu bağlamda, bölgede zeytinyağı üretimi yapan 2 adet yerel zeytinyağı markası (Zeytinos Kastabala ve Beymail) da yer almaktadır (Osmaniye Ticaret ve Sanayi Odası, 2016). Dolayısıyla, zeytinyağı üretimi konusunda son yıllarda ön plana çıkan Osmaniye'nin bu ürünün tanımını (üretilen zeytinlerin en önemli tanıtıcı unsuru) yaparak, gerek üretim yerini ve üretim metodunu gerekse de ürünün ayırt edici özelliklerini (duyusal ve kimyasal özellikler gibi) ortaya koyarak ilgili kurum/kuruluşlar tarafından coğrafi işaret tescil başvurusu yapabileceği ifade edilebilir. Ayrıca zeytinyağıyla yapılacak olan zeytinyağlı sabun gibi ürünlerin de coğrafi işaret potansiyeli taşıdığı göz önüne alındığında bu konuda da ildeki paydaşların coğrafi işaret başvurusunu gerçekleştirebileceği söylenebilir.

Ahşap Oymacılığı: Osmaniye ilinde coğrafi işaret potansiyeli taşıyan bir diğer ürün ise el işçiliği ürünü olan ahşap oymacılığıdır. Bu ürünle ilgili herhangi kurum veya kuruluş tarafından resmi olarak coğrafi işaret tescil başvurusu yapılmamıştır. Osmaniye'de ahşap oymacılığının üretim yerinin Kadirli ilçesi, Kızyusuflu köyü olduğu belirtilmektedir. Genellikle, bölgenin tarihi ve doğal güzellikleri ahşap oymacılığına işlenmektedir. Yörede yetişen keklik gibi kuş çeşitleri ve tarihte yaşamış krallardan Asativatas'ın heykeli bu örneklerden bazılarıdır. Ayrıca, mutfak eşyaları (kaşık gibi) ve müzik aletleri de işlenmektedir. Ahşap oymacılığının birçok farklı modeli yapıldığı için kullanılan ağaç da oyulan figüre göre değişmektedir. Örneğin, dut ağacı, karadal diye bilinen karacan ağacı ve ardıç ağacı müzik aleti yapımında, sandal (hartlap) ağacı ise mutfak eşyaları yapımında kullanılmaktadır. Özellikle, kendine has kokusu ve damarlı yapısı nedeniyle sandal ağacından oyulan figürler diğer ürünlerden ayrılmaktadır (Doğu Akdeniz Kalkınma Ajansı, 2018: 65). Bu bağlamda, bölgeye özgü figürlerin oyulması ve bu figürlerle bölgedeki tarihi ve doğal güzelliklere dikkat çekilmesi, bu ürünlerin coğrafi işaret tesciliyle korunmasını gerekli kılmaktadır. Dolayısıyla, ilgili kurum ve kuruluşlar tarafından bu konuda gerekli araștırmalar yapılarak, spesifik olarak belirtilecek bir figürle (keklik oymacılığı, tahta kașık oymacılığı gibi) ilgili olarak mahreç işareti kapsamında tescil başvurusu gerçekleştirilebilir.

\section{Sonuç}

Çalışmadaki amaç, Osmaniye'nin coğrafi işarete konu olabilecek ürünlerinin tespit edilmesidir. Bu amaçla, Osmaniye ilinin coğrafi işaret kapsamında değerlendirilebilecek ürünleri incelenerek, bu ürünlerin coğrafi sınırları, ürün çeşidi ve ürünlerin ayırt edici özellikleri gibi detaylara yer verilmiştir. Çalışma sonucunda, coğrafi işaret tescili alan veya coğrafi işaret potansiyeli taşıyan ürünlerin (Kadirli turpu, Osmaniye Karatepe kilimleri, defne yaprağı, Osmaniye zeytinyağı ve ahşap oymacılığı) genellikle, tarımsal ve el sanatları ürünleri olduğu ortaya çıkmıştır. Dolayısıyla, Osmaniye ilinin üretilen gıda/tarım ürünleri, zengin içeriği, çeşitliliği ve taşıdığı kültür ve iklimsel özellikleri itibariyle birçok ürün bazında coğrafi işaret potansiyeline sahip olduğu tespit edilmiştir. Osmaniye ili gibi alanyazında Akdeniz Bölgesi'nde yer alan birçok farklı ilin coğrafi işaretler açısından zengin bir potansiyele sahip olduğunu ortaya koyan çalıșmalar yer almaktadır (Çalışkan ve Koç, 2012; Dayısoylu, Yörükoğlu ve Ançel, 2017; Kantaroğlu ve Demirbaş, 2018; Boyraz, 2019). Ancak, söz konusu çalışmalardaki diğer illerle kıyaslandığında Osmaniye ili, coğrafi işaret potansiyeli taşıyan ürünleri için tescil başvurusu konusuna gereken önemi özellikle son yıllarda sergilemesine rağmen, bu potansiyeli tam olarak harekete geçirmekte zorlanmaktadır. Mevcut bu potansiyelin harekete geçirilmesi, coğrafi işaretli ürünlerin bölgeye sağladığı katkılardan daha fazla yararlanması ve coğrafi işaret koruması ile ürünlerin gelecek nesillere bozulmadan aktarılması için ilde önemli rol üstlenen kurum ve kuruluşların ilin coğrafi işaret potansiyeli taşıyan ürünlerini tespit ederek tescil başvurularını yapması önerilmektedir. Bu durumun sağlıklı bir şekilde gerçekleştirilmesi amacıyla bölgedeki ilgili kurum ve kuruluşlar, paydaşlarla iş birliği yapmalı ve coğrafi işaret potansiyeli taşıyan ürünlerin tespit edilmesi amacıyla uzman kişilerden görüş alınmalıdır. Bu kapsamda öncelikle, envanter çalışması yapılarak ilin sahip olduğu tüm ürünlere ve niteliklerine ilişkin veri havuzu oluşturulması, ardından ise 
coğrafi işaret tescili alma potansiyeli olan ürünlerin, önem derecesine göre sınıflandırılması gerekmektedir. Bu noktada, ilin üst düzey yerel yöneticileri tarafından kurum ve kuruluşlar arası takip ve görevlendirmeler yapılmalı ve coğrafi işaret başvurusu için süreçler takip edilmelidir. Özellikle, düzenli olarak her yıl "coğrafi işaret günleri” yapılarak bölgenin coğrafi işaretli ürün potansiyeli alanında uzman kişilerle tartışılmalıdır. Ayrıca, üniversiteler, yerel ve bölgesel kalkınma ajansları oluşturulacak olan projeler ile coğrafi işaretli ürünlerin değerlendirilmesi hususunda öncülük edebilirler. Diğer taraftan, yerel kurum ve kuruluşların coğrafi işaret başvurularını hazırlarken incelenen ürünle ilgili olarak coğrafi bağlantının kurulması için coğrafya bölümlerinden destek ve iş birliği istemeleri, doğal ve beşerî faktörlerin sentezinin sağlanmasına katkı sağlayacaktır. Dolayısıyla, Osmaniye'de coğrafi işaret potansiyeli taşıyan ürünlerin tescillenerek yasal koruma altına girmesi, bu ürünlerin bölgeye özgü olarak değerlendirilmesine ve bölgenin yararına kullanılmasına yardımcı olacağı gibi ilde üretilen diğer ürünlere olan talebi arttırarak bölgedeki hizmetlerin gelişimini destekleyici rol üstlenebilecektir.

Çalışmada, coğrafi işaretler konusunda ileride yapılacak olan akademik çalışmalara yönelik birtakım önerilerde bulunmakta fayda görülmektedir. Osmaniye'nin coğrafi işaret potansiyelinin incelendiği bu çalışmada, arşiv-doküman yöntemiyle veri toplanmıştır. İleride gerçekleştirilecek olan çalışmalarda özellikle yöredeki ilgili kurum ve kuruluş temsilcileriyle görüşme yöntemiyle de verilerin toplanması konunun derinlemesine incelenmesine ve coğrafi işarete konu olabilecek ürünlerin ortaya çıkarılmasına katkı sağlayacaktır. Ayrıca, lisansüstü öğrencilerin ve akademisyenlerin coğrafi işaretler konusunda çalışmalar gerçekleştirmesi, konunun bilinirliğini artıracak ve coğrafi işarete konu olan ürünün üretildiği bölgeye olan ilgiyi/talebi yükseltecektir. Her çalışmada söz konusu olduğu gibi bu çalışmanın da bazı sınırlılıkları bulunmaktadır. Çalışmadaki en önemli kısıt, nitel veri toplama yönteminin tercih edilmesidir. Söz konusu durum, araştırma sonuçlarını evrene genelleme açısından sınırlandırdığı için ileride gerçekleştirilecek çalışmalarda, nicel veriler toplanarak daha genellenebilir sonuçlar elde edilebilir. Çalışmadaki bir diğer kısıt ise, Osmaniye'nin coğrafi işaret potansiyeline yönelik değerlendirmeler sadece ilgili kişi, kurum ve kuruluş temsilcilerinin görüşleriyle sınırlı kalmıştır. Benzer araştırmalar konu ile ilgili olan özellikle yerel halk üzerinde ve ürünlerin üreticilerine yönelik olarak da gerçekleştirilebilir

\section{Kaynakça}

Acar, Y. (2018). Türkiye'deki Coğrafi İşaretli Ürünlerin Destinasyon Markalaması Kapsamında Değerlendirilmesi. Journal of Tourism and Gastronomy Studies, 6(2), 163-177.

Addor, F., Thumn, N. \& Grazioli, A. (2003). Geographical Indications: Important Issues for Industrialized and Developing Countries. The IPTS Report (Institute for Prospective Technological Studies), 74, 1-12.

Agostino, M. \& Trivieri, F. (2014). Geographical Indication and Wine Exports. An Empirical Investigation Considering the Major European Producers. Journal of Food Policy, 46, 22-36.

Akan, S., Veziroğlu, S., Özgün, Ö. \& Ellialtıoğlu, Ş. (2013). Turp (Raphanus Sativus L.) Sebzesinin Fonksiyonel Gıda Olarak Değerlendirilmesi. Yüzüncü Yıl Üniversitesi Tarım Bilimleri Dergisi, 23(3), 289-295.

Arfini, F., Albisu, L. M. \& Giocomini, C. (2011). “Current Situation and Potential Development of Geographical Indications in Europe". (Ed. E. Barham ve B. Sylvander) International Labels of Origin for Food. Local Development, Global Recognation, CAB International, London, UK.

Artık, N., Şanlıer, N. \& Sezgin, A. C. (2019). Gıda Kontrolü ve Mevzuatı. Vize Yayıncılık, Ankara.

Arslaner, A. \& Salık, M. A. (2018). Potansiyel Bir Coğrafi İşaret: Saruç. Erzincan Üniversitesi Fen Bilimleri Enstitüsü Dergisi, 11(1), 74-84.

Babcock A. B. \& Clemens, R. (2004). Geographical Indications and Property Rights: Protecting Value Added Agricultural Products. MATRIC (Midwest Agribusiness Trade Research and Information Center) Briefing Papers, Iowa State University, USA.

Bowen, S. \& Zapata, A. V. (2009). Geographical Indications, Terroir and Socioeconomic and Ecological Sustainability: The Case of Tequila. Journal of Rural Studies, 25, 108-119.

Boyraz, M. (2019). Coğrafi İşaretli Ürünler: Afyonkarahisar. International Journal Entrepreneurship and Management Inquiries (Journal EMI) Dergisi, 3(4), 26-46. 
Bramley, C. \& Kirsten, J. F. (2007). Exploring the Economic Rationale for Protecting Geographical İndicators in Agriculture. Agrekon, 46(1), 47-71.

Bucak, T. (2018). “Coğrafi İşaretleme”. (Ed. A. Akbaba ve N. Çetinkaya), Gastronomi ve Yiyecek Tarihi, (ss. 373391), Detay Yayıncılık, Ankara.

Bulut, İ. \& Fural, Ş. (2018). Serik Bıçağı'nın Coğrafi İşaret Tescili Kapsamında Değerlendirilmesi. Atatürk Üniversitesi Sosyal Bilimler Enstitüsü Dergisi, 22(Özel Sayı), 557-580.

Chandola, H. V. (2006). Basmati Rice: Geographical Indication or Mis-İndication. The Journal of World Intellectual Property, 9(2), 166-188.

Coombe, R. J., Ives, S. \& Huizenga, D. (2014). Geographical Indications: The Promise, Perils and Politics of Protecting Place-Based Products. The SAGE Handbook of Intellectual Property. London.

Çalışkan, V. \& Koç, H. (2012). Türkiye'de Coğrafi İşaretlerin Dağılış Özelliklerinin ve Coğrafi İşaret Potansiyelinin Değerlendirilmesi. Doğu Coğrafya Dergisi, 17(28), 193-214.

Çekal, N. \& Aslan, B. (2017). Gastronomik Bir Değer Olarak Tarhana ve Coğrafi İşaretlemede Tarhananın Yeri ve Önemi. Güncel Turizm Araştırmaları Dergisi, 1(2), 124-135.

Çukur, F. \& Çukur, T. (20179. Coğrafi İşaretli Ürünlerin Kırsal Kalkınma Açısından Değerlendirilmesi: Muğla İli Örneği. Tarım Ekonomisi Dergisi, 23 (2), 187-194.

Dağtekin, E. E. (2018). Coğrafi İşaret Olarak Diyarbakır Bazalt Taşı ve Tescili. Elektronik Sosyal Bilimler Dergisi, 17(66), 851-860.

Dayısoylu, K. S., Yörükoğlu, T. \& Ançel, T. (2017). Kahramanmaraş'ın Coğrafi İşaretli Ürünleri ve İlin Potansiyel Durumu. KSÜ Doğa Bilimleri Dergisi, 20(1), 80- 88.

Dede, S. \& Didin, M. (2017). Coğrafi İşaretli Ürünlerin Gerçekliği, Orijini ve İzlenebilirliğinde Nanoenkapsülasyon Teknolojilerinin Kullanımının Araştırılması. Mustafa Kemal Üniversitesi Ziraat Fakültesi Dergisi, 22(2), 97106.

Demir, M. (2016). Coğrafi İşaret Örneği Olarak Kars Kaşar Peynirinin Üretimi ve Dağılımı. Kafkas Üniversitesi Sosyal Bilimler Enstitüsü Dergisi, 1, 61-81.

Dikici, A., Koluman, A. \& Aktaș, R.K. (2013). Gıdaların Coğrafi İşaretlenmesi. İstanbul Üniversitesi Veteriner Fakültesi Dergisi, 39(1), 136-138.

Dimara, E., Petrou, A. \& Skuras, D. (2004). Agricultural Policy for Quality and Producers' Evaluations of Quality Marketing Indicators: A Greek Case Study. Food Policy, 29(5), 485-506.

Doğan, B. (2015). Coğrafi İşaret Korumasının Gelişmekte Olan Ülkeler İçin Önemi. E-Journal of New World Sciences Academy, 10(2), 58-75.

Doğu Akdeniz Kalkınma Ajansı, (2018). “TR 63 Bölgesi Yöresel Ürünler Kataloğu”. Erişim Tarihi: 05.12.2019, http://www.dogaka.gov.tr/

Doğu Akdeniz Kalkınma Ajansı, (2018). “Osmaniye Zeytin ve Zeytinyağı İmalatı”. Erişim Tarihi: 05.12.2019, htpp: http://www.dogaka.gov.tr/

Gangjee, D. S. (2015). Geographical Indications and Cultural Rights: The Intangible Cultural Heritage Connection?". (Ed. C. Geiger), Research Handbook on Human Rights and Intellectual Property, pp. 544559, Edward Elgar Publishing, Cheltenham.

Gökovalı, U. (2007). Coğrafi İşaretler ve Ekonomik Etkileri: Türkiye Örneği. İktisadi ve İdari Bilimler Dergisi, 21(2), 141-160.

Gürel, E. vd. (2016). Coğrafi İşaretlerin Kırsal Kalkınma Açısından Değerlendirilmesi: Tokat İli Örneği. XII. Tarım Ekonomisi Kongresi (1049-1058), 23-27 Mayıs 2016, Süleyman Demirel Üniversitesi, Isparta.

Hatipoğlu, B. (2016). Bölgesel Turizmde Coğrafi İşaretli Yiyecek İçeceklerin Yeri: Tramep Proje Örneği. (Ed. Ö. Bardakoğlu ve V. Tecim), Bölgesel Turizm, ss. 80-91, DEUZEM, İzmir. 
Hazarhun, E. \& Tepeci, M. (2018). Coğrafi İșarete Sahip Olan Yöresel Ürün ve Yemeklerin Manisa'nın Gastronomi Turizminin Gelişimine Katkısı. Güncel Turizm Araştırmaları Dergisi, 2, 371-389.

Jay, T. \& Taylor, M. (2013). A Case of Champagne: A Study of Geographical Indications. Corporate Governance eJournal, Faculty of Law. 1-32.

Kadirli Belediyesi, (2019). “Kadirli Turpu”. Erişim Tarihi: 05.12.2019, https://www.kadirli.bel.tr/

Kan M. \& Gülçubuk, B. (2008). Kırsal Ekonominin Canlanmasında ve Yerel Sahiplenmede Coğrafi İșaretler. Uludağ Üniversitesi Ziraat Fakültesi Dergisi, 22(2), 57-66.

Kantaroğlu, M. \& Demirbaş, N. (2018). Türkiye'de Coğrafi İşaretli Gida Ürünleri Üretim Potansiyelinin Değerlendirilmesi. VIII. IBANESS Kongreler Serisi (514-520), 21-22 Nisan 2018, Plovdiv/Bulgaristan.

Karık, Ü. vd. (2015). Türkiye Defne (Laurusnobilis L.) Populasyonlarının Uçucu Yağ Bileşenleri. Anadolu Ege Tarımsal Araştırma Enstitüsü Dergisi, 25(1), 1-16.

Kaya, S. Y. \& Şahin, E. (2018). Tescilden Uygulamaya Coğrafi İşaretler: Adana Kebabı Üzerine Bir İnceleme. Güncel Turizm Araştırmaları Dergisi, 2(Ek.1), 189-199.

Lucatelli, S. (2004). Appellations of Origin and Geographical Indications in OECD Member Countries: Economic and Legal Implications. http://www.ictsd.org/ (Erişim Tarihi: 05.12.2019).

Mercan, Ş. O. \& Üzülmez, M. (2014). Coğrafi İşaretlerin Bölgesel Turizm Gelişimindeki Önemi: Çanakkale İli Örneği. Dokuz Eylül Üniversitesi İktisadi ve İdari Bilimler Fakültesi Dergisi, 29(2), 67-94.

Milliyet Gazetesi, (2018). “Defne Yaprağı”. Erişim Tarihi: 05.12.2019, http://www.milliyet.com.tr/

Osmaniye Ticaret ve Sanayi Odası, (2016). “Osmaniye İlinde Zeytin Yetiştiriciliği”. Erişim Tarihi: 05.12.2019, http://www.osmaiyetso.org.tr/

Öz, H. \& Dönmez, B. (2018). Yerel Gıda ve Coğrafi İşaretleme Kapsamında Süryani Şarabının Değerlendirilmesi. Güncel Turizm Araștırmaları Dergisi, 2(2), 260-269.

Polat, E. (2017). Turizm ve Coğrafi İşaretleme: Balıkesir Örneği. Meriç Uluslararası Sosyal ve Stratejik Araştırmalar Dergisi, 1(1), 17-31.

Ramos, B. D., Fernandes, L. R. R. de M. \& De Souza, C. G. (2012). An overview of Geographical Indications in Brazil. Journal of Intellectual Property Rights, 17, 133-140.

Rangnekar, D. (2004). The Socio-Economics of Geographical Indications. International Centre for Trade and Sustainable Development (ICTSD), Geneva, Switzerland.

Schneider, K. G. \& Ceritoğlu, A. B. (2010). Yöresel Ürün İmajının Tüketici Satın alma Davranışı ve Yüksek Fiyat Ödeme Eğilimi Üzerindeki Etkisi: İstanbul İlinde Bir Uygulama. Pazarlama ve Pazarlama Araştırmaları Dergisi, 6, 29-52.

Suh, J. \& MacPherson, A. (2007). The Impact of Geographical Indications on the Revitalisation of a Regional Economy: A case of “Boseong” Green Tea. Area 39(4), 518-527.

Suratno, B. (2004). Protection of Geographical Indications. IP Management Review, 2, 87-93.

Şahin, G. (2013). Hakkari'nin Nişaneleri ve Bunların Coğrafi İşaret Kapsamına Alınarak Ekonomiye Kazandırılması. Uluslararası Sosyal Araştırmalar Dergisi, 6(2), 479-493.

Şahin, G. (2014). Türkiye'de Yerfıstığı (Arachis Hypogaea L.) Yetiştiriciliği ve Bir Coğrafi İşaret Olarak Osmaniye Yerfıstığı. Gaziantep University Journal of Social Sciences, 13(3), 619-644.

Şahin, A. (2017). Gastromilliyetçilik Kavramının İncelenmesi: Coğrafi İşaret ve Markalaşma Faktörleri. Uluslararası Sosyal Araștırmalar Dergisi, 10(48), 459-464.

Toprak, L. \& Oğuz, Z. (2017). “Coğrafi İşaretler ve Siirt İli Örneği”. 18. Ulusal Turizm Kongresi Bildiri Kitabı, 1822 Ekim 2017, 964-973, Mardin.

TPE, (2019). “Osmaniye Yer Fıstığı”. Erişim Tarihi: 05.12.2019, https://www.ci.gov.tr/

TPE, (2019). “Kadirli Turpu". Erişim Tarihi: 05.12.2019, https://www.turkpatent.gov.tr/ 
TPE, (2019). “Karatepe Kilimleri”. Erişim Tarihi: 05.12.2019, https://www.ci.gov.tr/

TPE, (2020). “Coğrafi İşaretler”. Erişim Tarihi: 10.02.2020, https://www.ci.gov.tr/

Treager A., Filippo A., Giovanni B. \& Marescotti A. (2007). Regional Foods and Rural Development: The Role of Product Qualification. Journal of Rural Studies, 23, 12-22.

Üzülmez, M. \& Akdağ, G. (2019). Osmaniye İli Gastronomik Mirası ve Sürdürülebilirliği Üzerine Bir Araştırma. VIII. National IV. International Eastern Mediterranean Tourism Symposium, 19-20 Nisan 2019, 457-464, Anamur/Mersin.

Üzümcü, T. P., Alyakut, Ö. \& Akpulat, N. A. (2017). Coğrafi İşaretleme Kapsamında Kocaeli Gastronomik Ürünlerin Değerlendirilmesi. KMU Sosyal ve Ekonomik Araştırmalar Dergisi, 19(28), 132-140.

Yeşildağ, G. N. G., Özata, E. \& Akkaya, A. (2017). Gastronomi Üzerine Araştırmalar (Ed. D. Bozok, C. Avcıkurt, M. Doğdubay, M. Sarıoğlan ve G. K. Girgin) Coğrafi İşaretli Gastronomi Ürünleri Üzerine Bir Araștırma: Erzurum İli Örneği, ss. 175-184), Detay Yayıncılık, Ankara.

Yıldırım, A. \& Şimşek, H. (2013). Sosyal Bilimlerde Nitel Araştırma Yöntemleri. Seçkin Yayıncılık, Ankara.

Zografos, D. (2008). Geographical Indications and Socio-Economic Development. IQSensato Working Paper 3, 112. 